\title{
Effect of rainfall on loggerhead turtle nest temperatures, sand temperatures and hatchling sex
}

\author{
Alexandra Lolavar, Jeanette Wyneken* \\ Department of Biological Sciences, Florida Atlantic University, 777 Glades Rd, Boca Raton, FL, USA
}

\begin{abstract}
Marine turtles deposit their eggs in underground nests where they develop unattended and without parental care. Incubation temperature varies with environmental conditions, including rainfall, sun/shade and sand type, and affects developmental rates, hatch and emergence success, and embryonic sex. We documented (1) rainfall and sand temperature relationships and (2) rainfall, nest temperatures and hatchling sex ratios at a loggerhead turtle (Caretta caretta) nesting beach in Boca Raton, Florida, USA, across the 2010 to 2013 nesting seasons. Rainfall data collected concurrently with sand temperatures at different depths showed that light rainfall affected surface sand; effects of the heaviest rainfall events tended to lower sand temperatures but the temperature fluctuations were small once upper nest depths were reached. This is important in understanding the potential impacts of rainfall as a modifier of nest temperatures, as such changes can be quite small. Nest temperature profiles were synchronized with rainfall data from weather services to identify relationships with hatchling sex ratios. The sex of each turtle was verified laparoscopically to provide empirical measures of sex ratio for the nest and nesting beach. The majority of hatchlings in the samples were female, suggesting that across the 4 seasons most nest temperatures were not sufficiently cool to produce males. However, in the early portion of the nesting season and in wet years, nest temperatures were cooler, and significantly more males hatched.
\end{abstract}

KEY WORDS: Temperature-dependent sex determination $\cdot$ Caretta caretta $\cdot$ Environment $\cdot$ Nests $\cdot$ Florida $\cdot$ Weather $\cdot$ Sea turtle

\section{INTRODUCTION}

During development, sea turtle hatchling sex is directed by temperature (Bull 1980, Mrosovsky \& Yntema 1980, Girondot 1999). In sea turtle species, male-biased sex ratios occur when nest temperatures are cooler $\left(<29\right.$ to $30^{\circ} \mathrm{C}$ in most species) and femalebiased sex ratios occur at warmer temperatures (Miller \& Limpus 1981, Standora \& Spotila 1985, Pieau et al. 1995). The developing gonad is directed to be male or female during the thermosensitive period (TSP), which occurs in the middle third of development (33 to $66 \%$ of incubation) when incubation temperatures are held constant or vary over a narrow temperature range (Mrosovsky \& Yntema 1980). An additional study narrowed the TSP to 50 to

\footnotetext{
*Corresponding author: jwyneken@fau.edu
}

$66 \%$ of incubation duration (Raynaud \& Pieau 1985). Several controlled laboratory studies identified the temperature/sex ratio response relationship as sigmoidal; the inflection point of the curve is the pivotal temperature, at which the sex ratio response model gives a 1:1 sex ratio. The pivotal temperature for the loggerhead turtle Caretta caretta is estimated to be $\sim 29.0^{\circ} \mathrm{C}$ (Mrosovsky 1988, Wibbels 2003, Blair 2005). The transitional range of temperatures (TRT) across which both sexes may occur spans 26.5 to $32^{\circ} \mathrm{C}$ (Bull 1980, Wibbels 2003, Blair 2005). Earlier studies suggest mean temperature of the incubation period can predict hatchling sex ratios (Bull 1985, Mrosovsky \& Provancha 1992, Mrosovsky 1994); however, several recent studies suggest that measures of temperature variation are better predictors of hatching sex in

() The authors 2015. Open Access under Creative Commons by Attribution Licence. Use, distribution and reproduction are unrestricted. Authors and original publication must be credited. Publisher: Inter-Research · www.int-res.com 
some turtle species (Georges at al. 2004, Girondot et al. 2010, Telemeco et al. 2013a).

In addition to genetic variation and possible maternal effects, environmental factors, such as sand albedo (Hays et al. 2001), shading and sun exposure (Standora \& Spotila 1985), and moisture from rainfall (Godfrey et al. 1996, Houghton et al. 2007) may modify nest sex ratios. A number of studies suggest that the hydric environment, in combination with the thermal environment, influences embryonic development and phenotype, including sex in turtles (e.g., Packard et al. 1987, 1989, Cagle et al. 1993, Finkler 2006, LeBlanc \& Wibbels 2009, Wyneken \& Lolavar 2015). Moisture as rainfall may impact the nest environment, affecting hatchling size (McGehee 1990) and influencing hatchling sex (reviewed by Carthy et al. 2003, Wibbels 2003). Heavy rainfall decreases gas diffusion throughout the nest (Miller et al. 2003), which can cause egg death if extreme. Other sources of excess water, such as prolonged tidal inundation (Ragotzkie 1959, Kraemer \& Bell 1980) can also cause embryo death.

Field studies suggest that higher moisture during incubation influences hatchling sex ratios in turtles. Godfrey et al. (1996) found increased production of male hatchlings in green turtle (Chelonia mydas) and leatherback turtle (Dermochelys coriacea) nests during April and May, months with the most rainfall in Suriname. Additionally, Matsuzawa et al. (2002) examined nests in Japan and found sand temperature increased as the rainy season ended; thus moisture may influence the thermal environment of the nest. Houghton et al. (2007) found high rainfall in Granada produced unseasonably cool nest temperatures and interpreted these results as likely shifting leatherback sex ratios toward male-bias; however, sex ratio verification in this study was lacking. Wyneken \& Lolavar (2015) found that loggerhead nests incubated in years that were wetter than normal and nests incubated in the lab under hot and wet conditions produced more males than would be expected based on previous studies of sex ratio and incubation temperature (e.g. Mrosovsky \& Yntema 1980, Mrosovsky 1988).

We measured how rainfall affects sand temperatures as it travels down to nest depth, as moisture is an environmental factor that can change nest temperatures. We also investigated the relationships among rainfall amounts, loggerhead nest temperatures, and loggerhead hatchling sex ratio samples at a southeastern Florida nesting beach that has female-biased sex ratios (Rogers 2013, Wyneken \& Lolavar 2015). The nesting beaches along Florida's east coast are important because they produce the majority of the loggerhead hatchlings entering the Northwestern Atlantic Ocean (TEWG 2009). Thus, it is important to understand how environmental factors, specifically temperature and rainfall, influence hatchling sex ratios - a component of life history that can influence future reproduction.

\section{MATERIALS AND METHODS}

\section{Sand and rainfall}

To document the effects of rainfall on sand temperature at different depths, we placed Hobo ${ }^{\circledR}$ Model U22 dataloggers (accuracy $\pm 0.2^{\circ} \mathrm{C}_{i}$ Onset Computer) in the sand at 3 locations on a nesting beach in Boca Raton, Florida, during July and August 2014. The dataloggers were distributed throughout $\sim 1.4 \mathrm{~km}$ of the beach and were no closer than $2 \mathrm{~m}$ from the nearest nest. We recorded temperatures every $10 \mathrm{~min}$ for $30 \mathrm{~d}$.

The dataloggers were buried at 3 different depths: 5,18 , and $30 \mathrm{~cm}$ to create temperature profiles of the sand column above the level that may directly influence eggs. The dataloggers at $5 \mathrm{~cm}$ recorded the temperatures of surface sand. The top eggs of a loggerhead nest in Boca Raton are frequently at 26 to $32 \mathrm{~cm}$ (J. Wyneken unpubl. data). To help identify how temperature changes with depth, we included dataloggers at $18 \mathrm{~cm}$, which is above upper nest depth but below hottest surface sand, and at $30 \mathrm{~cm}$ to record sand temperatures at upper nest depth. Rain gauges (Stratus RG202M Metric Long Term Professional Rain and Snow Gauge, accuracy $\pm 0.02 \mathrm{~cm}$ ), located 5 to $12 \mathrm{~m}$ away from the dataloggers, recorded daily rainfall amounts at each location. The rainfall data were graphed in temporal synchrony with sand temperature data for each depth. Data were not normally distributed and were compared using Kruskal-Wallis tests (Zar 1999).

\section{Nest temperatures, rainfall and sex ratios}

Loggerhead Caretta caretta nests laid on the beaches of Boca Raton, Florida, USA $\left(26.1819^{\circ} \mathrm{N}\right.$, $80.0410^{\circ} \mathrm{W}$ to $26.3828^{\circ} \mathrm{N}, 80.0675^{\circ} \mathrm{W}$ ) during the 2010 to 2013 nesting seasons were marked ( $\mathrm{n}=9$ to 13 nests $\mathrm{yr}^{-1}$ ) and instrumented with temperature dataloggers. Nests were sampled throughout the entire nesting season (April to October). The nesting season was partitioned into 3 categories: early (April to mid-June), middle (mid-June through July), or late 
season (August through September). The eggs incubated in situ to allow normal environmental factors to influence the sex ratios.

Nest temperatures were recorded using Onset ${ }^{\circledR}$ Model U22 dataloggers. A datalogger was placed in the center of each clutch $(\sim 45 \mathrm{~cm})$ during nest deposition or a few hours afterwards. Nest temperatures (accuracy $\pm 0.2^{\circ} \mathrm{C}$ ) were recorded every $10 \mathrm{~min}$ throughout incubation. After the hatchlings emerged, dataloggers were removed and downloaded. Temperature data were recorded for the entire incubation duration (d) of each nest. We estimated the TSP from incubation duration in 2 ways: the middle third of the incubation period (33 to 66\%; TSP) and the later portion of the middle third (50 to $66 \%$; $\mathrm{TSP}_{\mathrm{L}}$ ).

During 2013, the datalogger from nest CC13-539 was excavated by a raccoon but was replaced after $5 \mathrm{~h}$. The thermal data were discarded for that $5 \mathrm{~h}$ period plus $2 \mathrm{~h}$ after the datalogger was repositioned and the nest cavity resealed with sand. One datalogger malfunctioned so no temperature data were recorded for nest CC13-271. No hatchlings were collected from nest CC13-317; however, temperature data and hatch and emergence success were recorded.

Local rainfall and weather data for the 2010 to 2013 nesting seasons (April to October) were obtained from the South Florida Water Management District's environmental database, DBHYDRO (SFWMD 2013), as well as the National Weather Service. Graphing rainfall data in daily synchrony with incubation temperature data identified rainfall effects on nest temperatures. Incubation temperatures were temporally synchronized with daily rainfall records. We matched the rainfall data by day with each nest's incubation temperature data for the same day so that shifts in nest temperatures associated with rainfall could be identified. Each nest's TSP was estimated and that portion of the temperature graph was used to identify whether rain cooling had had the potential to impact sex ratios. The presumed loggerhead pivotal temperature $\left(29.0^{\circ} \mathrm{C}\right)$ and TRT $\left(26.5-32^{\circ} \mathrm{C}\right)$ were used to identify relevant temperatures and interpret results.

Nests were monitored daily and the hatchlings from the initial major emergence were collected and brought to the Florida Atlantic University Marine Lab (Boca Raton, Florida, USA) where we quasi-randomly selected 10 morphologically normal loggerhead hatchlings from each clutch for later sex ratio sampling. We defined hatchlings as 'morphologically normal' by a lack of scute, flipper or head abnormalities, weighing $\sim 18 \mathrm{~g}$ and having a flattened plastron. The first major emergence was inferred to consist of the strongest hatchlings and those that might have the greatest chances of contributing to the population. The first major emergence typically includes hatchlings from a variety of positions in the clutch ( $\mathrm{J}$. Wyneken unpubl. data). If fewer than 10 hatchlings emerged, all of the available normal hatchlings were collected for the sex ratio sample. Nests were sampled from the first, middle, and last quartiles of the season so the entire nesting season was represented $(2010$, $\mathrm{n}=117$ hatchlings from 13 nests; $2011, \mathrm{n}=49$ hatchlings from 5 nests; 2012, $\mathrm{n}=95$ hatchlings from 11 nests; 2013, $\mathrm{n}=90$ hatchlings from 10 nests). In 2011, just 9 nests provided hatchlings.

After the hatchlings emerged, nests were inventoried for success. Hatch success is defined as the percentage of all eggs in the nest that hatch, and emergence success is defined as the percentage of hatchlings that emerged from the nest. C. caretta clutch size in Boca Raton averages 105 eggs per nest; the hatch success is $\sim 78 \%$ and average emergence success is $\sim 75 \%$ (J. Wyneken unpubl. data). In some cases, sampling was not possible due to temperature datalogger failure, nest losses to storms or hatchlings escaping before they could be collected.

To identify relationships among nest temperature, daily rainfall amount and hatchling sex ratio, we graphed daily rainfall in temporal synchrony with incubation temperatures of each sampled nest. We empirically evaluated whether higher amounts of rainfall were associated with lower nest temperatures and if that correlated with higher male production. Nest temperatures were summarized graphically and as ranges during the estimated TSP. Comparisons were made using Kruskal-Wallis and Mann-Whitney tests.

Collected turtles were raised in the lab to $120 \mathrm{~g}$, then sex was identified laparoscopically (Wyneken et al. 2007). Sex ratios reported are for the sample, which represents about $10 \%$ of the eggs for each nest. Following laparoscopic exam, the turtles were kept in the lab for a minimum of $1 \mathrm{wk}$ to ensure full recovery and then were released offshore into the Gulf Stream current. The Florida Atlantic University IACUC authorized the studies, which were permitted under Florida Marine Turtle Permit 073.

\section{RESULTS}

\section{Sand temperatures and rainfall}

Sand temperatures at the same depth, independent of turtle nests and rainfall amounts, were compared 
at 3 locations for the same time period. Temperatures at all depths and locations experienced daily fluctuations associated with diurnal heating and nocturnal cooling. However, the amplitude of these fluctuations decreased with depth (Fig. 1). Sand temperatures at $5 \mathrm{~cm}$ and at $18 \mathrm{~cm}$ were not statistically different at the 3 locations (Kruskal-Wallis; $H=1.57, \mathrm{p}>0.05$ at $5 \mathrm{~cm} ; H=1.91, \mathrm{p}>0.05$ at $18 \mathrm{~cm})$. However, sand temperatures at $30 \mathrm{~cm}$ differed among the 3 locations (Kruskal-Wallis; $H=8.85, \mathrm{p}=0.012$ ). Mann-Whitney $U$-tests indicated that sand temperatures at $30 \mathrm{~cm}$ in all locations differed from each other (Locations 1 vs.
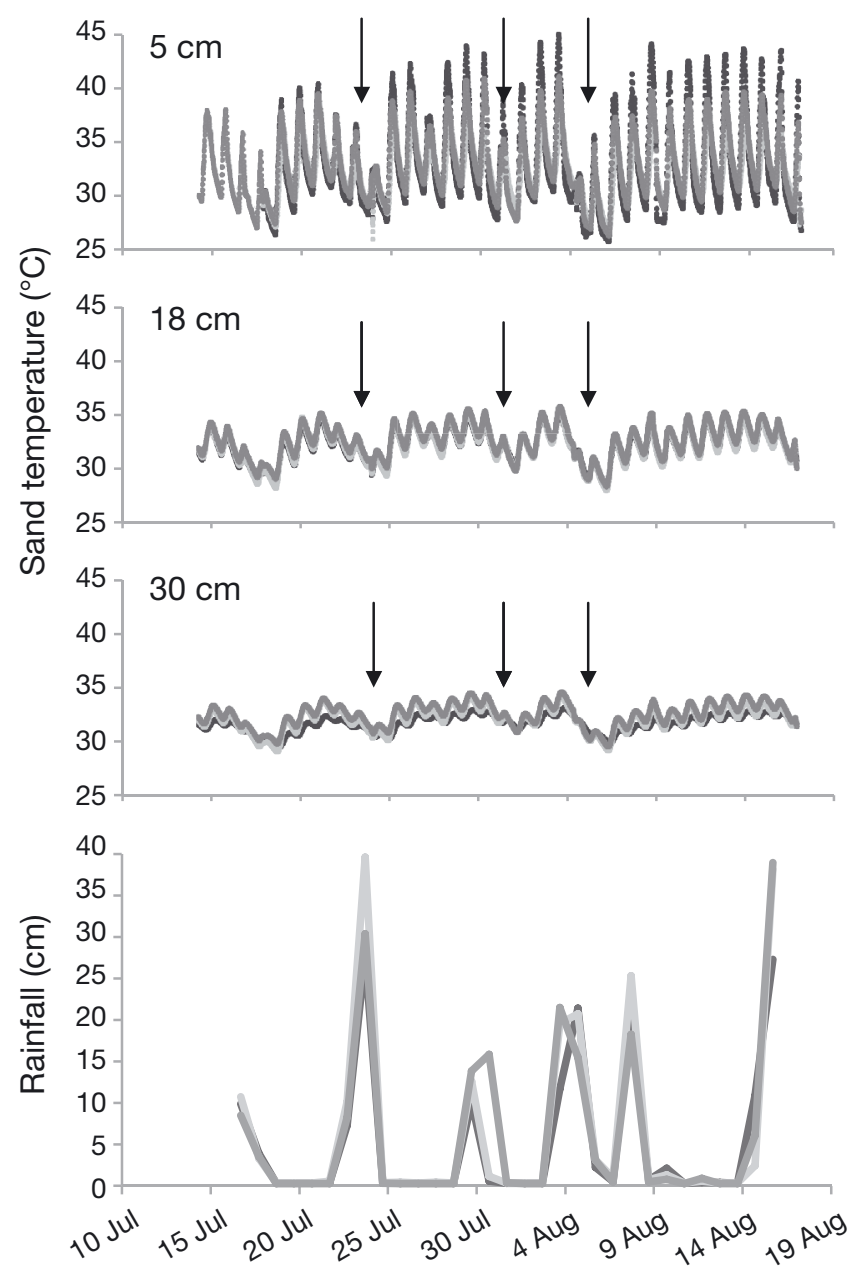

Fig. 1. Impact of rainfall on sand temperature at 3 depths $(5,18$, and $30 \mathrm{~cm})$ from 3 loggerhead nesting beach locations at Boca Raton, Florida, from July 10 to August 19, 2014. Upper 3 graphs are sand temperatures: dark gray shows Location 1, light gray shows Location 2, and medium gray shows Location 3. Arrows identify decreased sand temperature with greater rainfall. Bottom graph is rainfall (in $\mathrm{cm}$ ) at the same locations and on the same dates as the thermal data. Rainfall and sand temperature data at 5 and $18 \mathrm{~cm}$ at different locations did not statistically differ; sand temperatures after rainfall differed significantly at different depths
2: $H=4.62$; Locations 2 vs. $3: H=4.01$; Locations 1 vs. 3: $H=9.85 ; \mathrm{p}<0.05$ for each comparison). Temperatures of surface sand increased and decreased more quickly than deeper sand. Sand temperatures warmed up to $\sim 44^{\circ} \mathrm{C}$ at $5 \mathrm{~cm}$, while sand at $18 \mathrm{~cm}$ and $30 \mathrm{~cm}$ warmed to $\sim 37^{\circ} \mathrm{C}$ and $\sim 34^{\circ} \mathrm{C}$, respectively. Similarly, cooling effects from rain were also less extreme with depth; mean sand temperatures during heavy rain events decreased to $\sim 26^{\circ} \mathrm{C}, 28^{\circ} \mathrm{C}$, and $29^{\circ} \mathrm{C}$ at $5 \mathrm{~cm}$, $18 \mathrm{~cm}$, and $30 \mathrm{~cm}$, respectively.

Rainfall amounts among the 3 sample locations were not statistically different (Kruskal-Wallis; $H=$ $0.11, \mathrm{p}>0.05)$.

Sand temperatures decreased with sand depth at all locations (Fig. 1) and were statistically different among the 3 depths at all locations (Kruskal-Wallis; Location 1: $H=11.73$, Location $2: H=9.03$, Location 3: $H=6.76$; $\mathrm{p}<0.05$ for each comparison). At shallower sand depths, rainfall caused greater cooling. Periods without rain or cloud cover caused greater surface sand heating than at deeper depths.

Average and standard errors of temperature oscillation ranges associated with rainfall for all locations were $11.47 \pm 1.1^{\circ} \mathrm{C}(5 \mathrm{~cm}) ; 5.09 \pm 0.3^{\circ} \mathrm{C}(18 \mathrm{~cm}) ; 2.89$ $\pm 0.3^{\circ} \mathrm{C}(30 \mathrm{~cm})$. A $27.4 \mathrm{~cm}$ rainfall event at Location 1 caused sand temperature at $5 \mathrm{~cm}$ depth to decrease by $\sim 10.5^{\circ} \mathrm{C}$, at $18 \mathrm{~cm}$ to decrease by $\sim 4.9^{\circ} \mathrm{C}$, and at $30 \mathrm{~cm}$ to decrease by $\sim 3.1^{\circ} \mathrm{C}$ (Fig. 1). After rainfall, temperature changes at all 3 depths lasted roughly the same amount of time $(\sim 4 \mathrm{~d})$. Otherwise, there were few temperature differences among the same depths at different locations.

Hot nesting seasons: 2010 and 2011

The summer air temperatures in 2010 were record highs for coastal regions to the north and south of our site (West Palm Beach, Fort Lauderdale and Miami); recorded temperatures ranged from 2 to $2.4^{\circ} \mathrm{C}$ above normal temperatures (NWS 2010). Periods without rain coincided with rapid increases in nest temperature concurrent with very warm daily air temperatures. The 2010 rainy season lasted $141 \mathrm{~d}, 12 \mathrm{~d}$ shorter than the long-term average. Average wet season rainfall ranges from 89 to $114 \mathrm{~cm}$ (35 to 45 inches), usually lowest over coastal areas along both the Atlantic and Gulf coast (NWS 2012). The 2010 rainfall amounts measured at the fixed sampling stations averaged $\sim 102 \mathrm{~cm}$ ( 40 inches), although rainfall reaching the nesting beach was lower by several $\mathrm{cm}$. The 2010 rainy season was characterized by little cloud cover and widely varying rainfall amounts 
(NWS 2010). The National Weather Service (NWS) characterized 2011 as having higher than normal temperatures and 2011 was the warmest calendar year on record for West Palm Beach and Miami (north and south of our site). The 2011 rainy season was also shorter than average and lasted $133 \mathrm{~d}, 20 \mathrm{~d}$ less than average (NWS 2011).

In both years, several nests reached peak temperatures close to $36-37^{\circ} \mathrm{C}$ and produced live hatchlings (Table 1). All turtles sampled in 2010 and 2011 were

Table 1. Loggerhead turtle Caretta caretta nest metrics for 2010 to 2013 nesting seasons in Boca Raton, Florida, USA. Bolded rows in 2012 and 2013 indicate nests with cooler incubation temperatures that resulted in male-biased sex ratios. Temperature ranges are expressed as minimum and maximum values. Seasons: E, early season (April to mid-June); M, mid-season (midJune through July); L, late season (August through September). Duration: incubation duration in days. Thermosensitive period is the middle third (33-66\%; TSP) or the later portion of the middle third $\left(50-60 \%\right.$; $\mathrm{TSP}_{\mathrm{L}}$ ) of the incubation period

\begin{tabular}{|c|c|c|c|c|c|c|c|}
\hline $\begin{array}{l}\text { Year \& } \\
\text { nest ID }\end{array}$ & Season & $\begin{array}{c}\text { Date laid } \\
\text { (duration, d) }\end{array}$ & $\begin{array}{l}\text { Incubation } \\
\text { range }\left({ }^{\circ} \mathrm{C}\right)\end{array}$ & $\begin{array}{l}\text { TSP range } \\
\left({ }^{\circ} \mathrm{C}\right)\end{array}$ & $\begin{array}{c}\mathrm{TSP}_{\mathrm{L}} \text { range } \\
\left({ }^{\circ} \mathrm{C}\right)\end{array}$ & $\begin{array}{c}\text { Emergence, hatch } \\
\text { success }(\%)\end{array}$ & $\%$ female \\
\hline \multicolumn{8}{|l|}{2010} \\
\hline CC $10-2$ & $\mathrm{E}$ & 10 May (49) & $27.8-36.5$ & $30.6-33.8$ & $31.9-34.4$ & 24,42 & 100 \\
\hline CC $10-3$ & $\mathrm{E}$ & 11 May (50) & $28.3-35.9$ & $30.2-33.9$ & $31.0-33.7$ & 44,59 & 100 \\
\hline CC 10-4 & $\mathrm{E}$ & 15 May (54) & $27.7-34.7$ & $30.3-34.0$ & $32.0-34.0$ & 90,90 & 100 \\
\hline CC $10-15$ & $\mathrm{E}$ & 22 May (50) & $29.3-35.3$ & $31.4-34.8$ & $33.7-34.0$ & 33,37 & 100 \\
\hline CC $10-16$ & $\mathrm{E}$ & 22 May (51) & $28.6-34.1$ & $29.9-32.9$ & $31.5-32.8$ & 43,61 & 100 \\
\hline CC 10-34 & $\mathrm{E}$ & 28 May (47) & $30.1-35.9$ & $32.8-35.2$ & $33.9-34.9$ & 61,71 & 100 \\
\hline CC 10-37 & $\mathrm{E}$ & 28 May (47) & $29.4-35.0$ & $31.3-33.7$ & $32.5-33.4$ & & \\
\hline CC 10-65 & $E$ & 3 June (46) & $30.3-35.3$ & $32.7-33.9$ & $33.0-33.5$ & 58,65 & 100 \\
\hline CC 10-121 & $\mathrm{M}$ & 16 June (47) & $29.1-34.9$ & $29.1-34.0$ & $31.9-33.2$ & 61,65 & 100 \\
\hline CC 10-143 & $\mathrm{M}$ & 20 June (47) & $29.4-35.5$ & $29.4-34.3$ & $33.6-33.9$ & 47,47 & 100 \\
\hline CC 10-221 & M & 28 June (48) & $29.2-35.4$ & $32.2-34.8$ & $33.0-34.5$ & 41,58 & 100 \\
\hline CC $10-364$ & $\mathrm{M}$ & 22 July (50) & $30.7-35.0$ & $30.7-35.0$ & $33.7-33.9$ & 43,43 & 100 \\
\hline CC 10-389 & $\mathrm{M}$ & 26 July (48) & $30.0-34.6$ & $30.0-34.6$ & $32.4-34.1$ & 59,62 & 100 \\
\hline CC $10-420$ & $\mathrm{~L}$ & 6 Aug (49) & $30.8-34.5$ & $31.4-34.0$ & $31.4-32.8$ & 4,4 & 100 \\
\hline \multicolumn{8}{|l|}{2011} \\
\hline CC 11-36 & $\mathrm{E}$ & 16 May (49) & $27.6-35.0$ & $30.1-32.9$ & $31.0-32.6$ & 44,49 & 100 \\
\hline CC 11-40 & $\mathrm{E}$ & 18 May (49) & $28.4-35.1$ & $31.4-33.9$ & $31.7-33.8$ & 96,96 & 100 \\
\hline CC 11-44 & $E$ & 21 May (50) & $29.7-34.7$ & $31.1-34.2$ & $31.8-33.7$ & 98,98 & 100 \\
\hline CC 11-237 & $\mathrm{M}$ & 21 June (52) & $29.1-36.9$ & $29.7-36.6$ & $34.3-36.3$ & 15,21 & 100 \\
\hline CC 11-276 & M & 25 June (50) & $27.7-36.5$ & $32.1-35.6$ & $33.4-34.9$ & 49,67 & \\
\hline CC 11-284 & M & 26 June (52) & $28.5-35.9$ & $31.7-35.3$ & $33.8-35.0$ & 74,82 & 100 \\
\hline \multicolumn{8}{|l|}{2012} \\
\hline CC $12-2$ & $\mathrm{E}$ & 22 April (57) & & & & 0,87 & 0 \\
\hline CC 12-4 & $\mathbf{E}$ & 26 April (61) & $23.9-33.1$ & $26.6-31.5$ & $28.9-31.5$ & 77,98 & $\mathbf{0}$ \\
\hline CC 12-6 & $\mathrm{E}$ & 1 May (57) & $24.4-34.6$ & $26.6-32.6$ & $28.9-32.6$ & 0,97 & 100 \\
\hline CC $12-11$ & $\mathrm{E}$ & 3 May (57) & & & & 95,95 & 100 \\
\hline CC $12-287$ & M & 16 May (58) & & & & 79,91 & 100 \\
\hline CC 12-295 & M & 16 May (58) & & & & 95,95 & \\
\hline CC $12-453$ & M & 2 July (50) & & & & 77,78 & 100 \\
\hline CC $12-547$ & M & 8 July (47) & & & & 18,46 & 100 \\
\hline CC $12-730$ & $\mathrm{~L}$ & 26 July (51) & $24.8-33.5$ & $28.2-33.5$ & $28.2-33.5$ & 0,99 & 100 \\
\hline CC $12-745$ & $\mathrm{~L}$ & 30 July (54) & $27.7-33.9$ & $27.7-33.9$ & $27.7-33.9$ & 95,95 & 100 \\
\hline CC $12-749$ & $\mathrm{~L}$ & 31 July (52) & $22.3-33.1$ & $27.8-33.1$ & $27.8-32.4$ & 87,87 & 100 \\
\hline CC $12-756$ & $\mathrm{~L}$ & 3 Aug (51) & $27.5-33.9$ & $27.5-33.3$ & $29.0-33.3$ & 58,58 & \\
\hline CC $12-775$ & $\mathrm{~L}$ & 8 Aug (50) & $28.8-34.2$ & $28.8-34.2$ & $32.7-34.2$ & 14,26 & 100 \\
\hline \multicolumn{8}{|l|}{2013} \\
\hline CC 13-2 & $\mathbf{E}$ & 27 April (59) & $24.1-34.6$ & $27.5-30.8$ & $27.5-30.8$ & 87,91 & 12.5 \\
\hline CC 13-7 & $\mathbf{E}$ & 2 May (56) & $24.0-35.2$ & $26.8-30.8$ & $26.8-29.9$ & 87,95 & 20 \\
\hline CC 13-8 & $\mathbf{E}$ & 3 May (54) & $23.4-35.3$ & $26.9-30.6$ & $27.0-29.8$ & 19,92 & 0 \\
\hline CC 13-9 & $\mathbf{E}$ & 3 May (56) & $23.7-35.0$ & $27.5-30.6$ & $27.5-29.6$ & 89,95 & 20 \\
\hline CC $13-271$ & $\mathrm{M}$ & 20 June (46) & & & & 46,76 & 100 \\
\hline CC $13-317$ & $\mathrm{M}$ & 26 June (53) & $27.6-34.3$ & $27.6-32.7$ & $30.3-32.7$ & 96,98 & \\
\hline СС $13-389$ & $\mathrm{M}$ & 4 July (50) & $27.3-35.3$ & $28.1-33.0$ & $30.7-33.0$ & 29,61 & 100 \\
\hline CC $13-452$ & $\mathrm{M}$ & 11 July (52) & $28.0-36.1$ & $31.0-34.6$ & $31.4-34.6$ & 78,92 & 100 \\
\hline CC $13-39$ & $\mathrm{~L}$ & 20 July (48) & $28.8-35.9$ & $30.1-35.9$ & $31.1-35.9$ & 76,77 & 100 \\
\hline CC $13-574$ & $\mathrm{~L}$ & 25 July (49) & $29.0-35.3$ & $31.2-35.3$ & $31.7-35.3$ & 93,94 & 100 \\
\hline CC 13-662 & $\mathrm{L}$ & 24 Aug (52) & $28.1-33.4$ & $28.1-33.0$ & $28.9-32.0$ & 33,64 & 90 \\
\hline
\end{tabular}


females. Nest temperatures (Table 1) during these years, and particularly during the TSP remained relatively high. In 2010 and 2011, nests experienced temperature differences between the TSP and TSP as temperatures continually increased. In both years, incubation temperatures during the TSP and $\mathrm{TSP}_{\mathrm{L}}$ remained above the published loggerhead pivotal temperature $\left(29^{\circ} \mathrm{C}\right)$ and near or beyond the upper boundary of the TRT. Temporally synchronized graphs of nest temperatures and rainfall from 2010 showed that just 1 nest (CC10-121) experienced a large rainfall event that impacted temperatures during the TSP (Fig. 2). Nest CC10-121 reached its lowest temperature $\left(29.10^{\circ} \mathrm{C}\right)$ during the TSP after a rainfall event of $8.2 \mathrm{~cm}$. This temperature was close to the estimated pivotal temperature but only lasted for $\sim 3 \mathrm{~h}$. Temperatures rapidly increased, returning to and exceeding previous baseline temperatures recorded during the $\sim 8.5 \mathrm{~d}$ prior to the rainfall event. Rainfall events in 2010 and 2011 were infrequent or small, so nest temperatures changed little. Periods of little or no rainfall were associated with higher incubation temperatures (Fig. 2) than during rainfall. In 2010, no hatchlings were collected from nest $\mathrm{CC} 10-37$ so there is no recorded sex ratio, hatch or emergence success for this nest.

During 2011, temperature data were available for 6 early and middle season nests (Table 1). Both weather events and equipment failures combined to reduce sample sizes. Five late season nests were lost to storm tides, reducing the samples whose TSPs were during the warmest part of the season. No hatchlings from nest CC11-276 were collected so no sex ratio sample was acquired; however, emergence and hatch success were estimated upon nest inventory.

Wet nesting seasons: 2012 and 2013

The NWS characterized 2012 as cooler than 2010 and 2011, with temperatures near or below normal through November due to increased cloud cover and heavy rain (NWS 2012). The 2012 rainy season was extremely wet during the summer, particularly in southeast Florida, partially due to the effects of Tropical Storms Debby and Isaac and Hurricane Sandy. The 2012 rainy season began 1 wk earlier than in 2010 and 2011. Eastern Florida received near record amounts of rainfall from May to mid-October and there was extensive cloud cover. Eastern Palm Beach County, the location of our nests, received $128 \mathrm{~cm}$ of rain (SFWMD 2012). Average yearly rainfall of 114 to $152 \mathrm{~cm}$ (45 to 60 inches) fell from May to October
(NWS 2012). The longer rainy season and greater cloud cover provided a cooler incubation environment for 2012 nests. Similar to 2012, the 2013 nesting season was wetter than normal with each month of the rainy season featuring above normal rainfall amounts. Isolated areas in southeast Florida experienced over $127 \mathrm{~cm}$ (50 in) of rain and most areas received 89 to $114 \mathrm{~cm}$ (35 to 45 inches) (NWS 2013). May through July represented the wettest start to the rainy season in $45 \mathrm{yr}$ (NWS 2013). This time period coincides with the thermosensitive periods of most of the 2013 sampled nests.

In 2012, temperature data were collected from 4 early and 5 late season nests. Not all middle season nest temperatures were available due to equipment failures. However, emergence and hatch success were measured for all nests, and sex ratios were sampled for 11 nests. The first 2 nest samples (CC12-2 and CC12-4) were $100 \%$ male. The subsequent 9 nests provided $100 \%$ female hatchling samples. For all sampled nests, incubation temperatures ranged from below the pivotal temperature to near to or above the upper TRT boundary. Temperature data were obtained for only one of the $100 \%$ male samples, which had nest temperatures during the estimated TSP averaging around the pivotal temperature (Table 1). During incubation of the 2 all-male sample nests, rainfall events were frequent but tended to be small. Just 2 rainfall events yielded more than $6 \mathrm{~cm}$ (Fig. 2) and resulted in nest cooling that ranged from 4.3 to $5.1^{\circ} \mathrm{C}$. Late season nests experienced temperatures above the TRT. An $11.5 \mathrm{~cm}$ rainfall event on August 27, 2012, caused temperatures to drop to $27-29^{\circ} \mathrm{C}$ from $33-34^{\circ} \mathrm{C}$ for $\sim 4 \mathrm{~d}$ toward the end of several nests' TSP (Fig. 2; CC12-730 and CC12-745). However, these nests quickly returned to warmer temperatures, well above the pivotal temperature. All middle season and late season nest samples in 2012 were $100 \%$ female. Nests without associated sex ratio estimates were due to turtles escaping before they could be collected.

In 2013, early season nests experienced cooler temperatures, and hatchling samples were predominantly male. The first 4 nests of the season had highly male-biased sample sex ratios ( 0 to $20 \%$ female). The remaining 6 nests were from middle and late parts of the seasons; those samples were $100 \%$ female $(5$ nests) and $90 \%$ female (1 nest, CC13-662). Early season nest temperatures during the TSP fluctuated $\pm 1.5-2^{\circ} \mathrm{C}$ around the pivotal temperature (Table 1). These nests experienced cooler sand temperatures at the beginning of their incubation periods associated with a large rainfall event of $\sim 14.3 \mathrm{~cm}$. Two subse- 

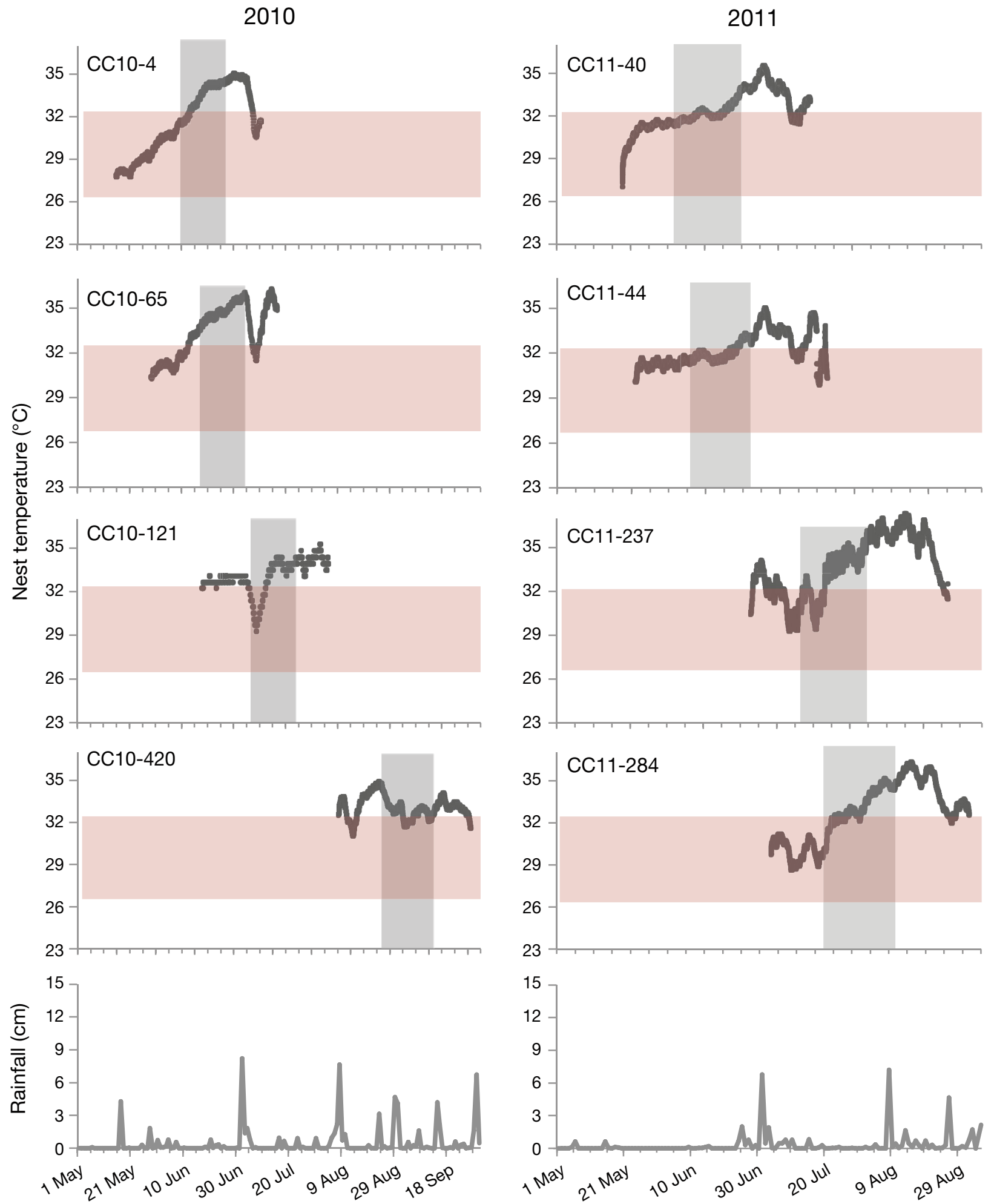

Fig. 2. (above and next page) Nest temperatures and rainfall for the 2010 to 2013 loggerhead turtle nesting seasons at Boca Raton, Florida. We selected temperature data for 4 example nests representative of each nesting season (top 4 rows for each year). Incubation temperatures measured in each nest are shown by the gray plot lines. The red shading indicates the published transitional range of temperatures (TRT) over which males and females may occur in Florida (Girondot 1999). The vertical gray boxes denote the predicted thermosensitive period (TSP) for each nest during which embryonic sex is determined. Rainfall $(\mathrm{cm})$ by year for the same nesting season dates is shown in the bottom row of graphs set 
2012
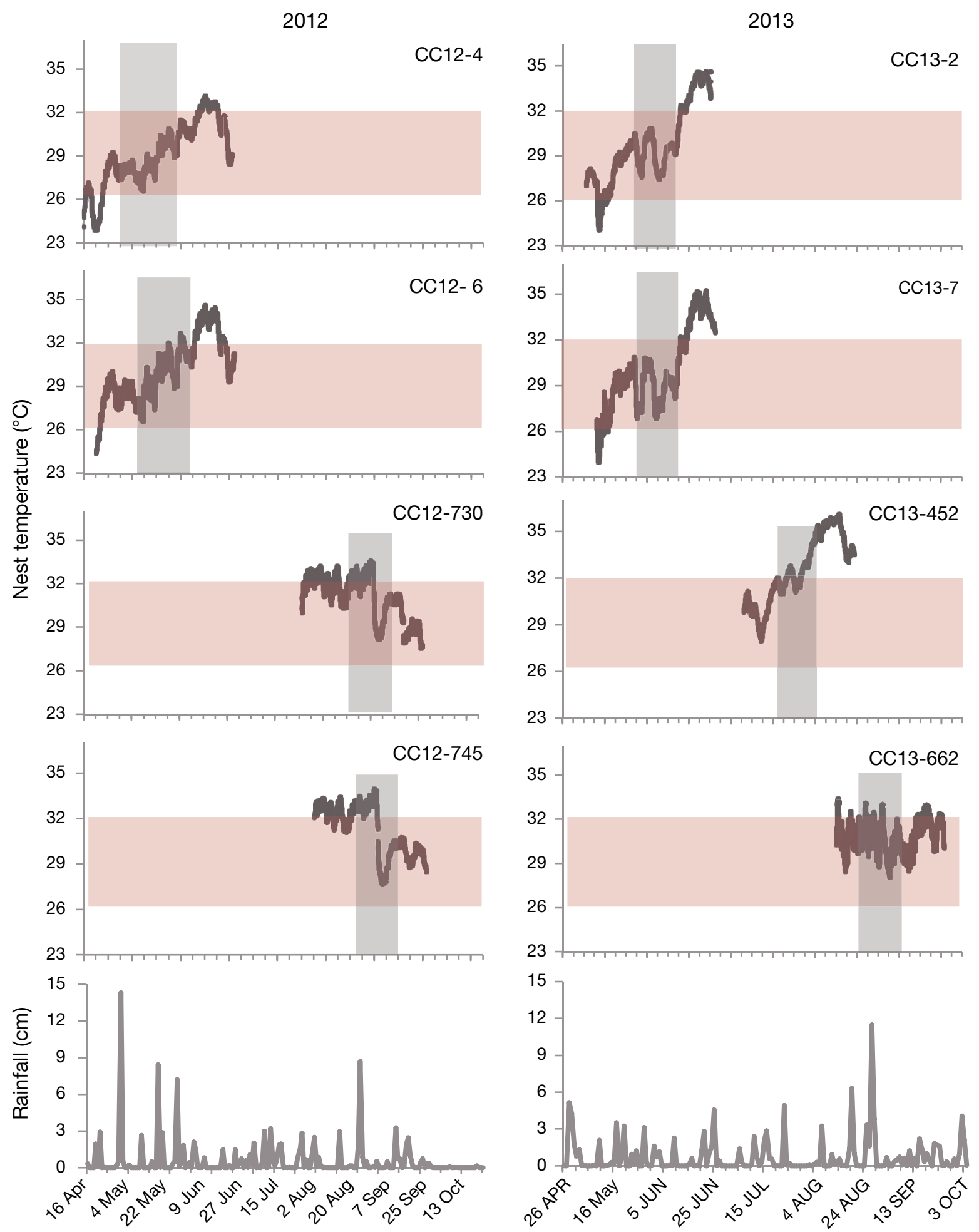

Fig. 2 (continued)

quent rainfall events of $\sim 8.4 \mathrm{~cm}$ and $\sim 7.2 \mathrm{~cm}$ further cooled early season nests, dropping nest temperatures below $27^{\circ} \mathrm{C}$ (Fig. 2). Smaller amounts of rain and cloud cover throughout the early portion of the season likely also contributed to cooling. After early season nest TSPs, fewer and smaller rainfall events occurred and temperatures quickly rose above the pivotal temperature and TRT. Mid- and late season nests experienced temperatures above the pivotal temperature and TRT for the majority of their TSPs. 
Late season nests also experienced high temperatures but a $\sim 8.7 \mathrm{~cm}$ rainfall event and subsequent smaller rainfall amounts led to fluctuating temperatures rather than the steady increase experienced by early and middle season nests. Nest CC13-662 experienced lower temperatures than other late season nests. During its TSP, temperatures decreased to $\sim 28^{\circ} \mathrm{C}$ and remained within the TRT (Fig. 2).

\section{DISCUSSION}

\section{Sand temperatures and rainfall}

The findings from this study are important for understanding the effects of weather and climate at the beach surface vs. the nest level. The low amplitude changes and cooler temperatures at the deeper sand position (upper nest level) suggest that the impact of increased air temperatures is lesser here than for shallower sand. Moreover, precipitation must be greater to have an effect on deeper sand compared to sand near the surface. If turtles lay shallower nests, the effects can, theoretically, be more pronounced than the effects on deeper nests. Further, rainfall events cooled the upper sand layers more than deeper sand. Thus, there is a graded influence of moisture that is smallest at the level where eggs could be affected, should they be present. Larger variations among sand temperatures at $5 \mathrm{~cm}$ compared to $18 \mathrm{~cm}$ and $30 \mathrm{~cm}$ are consistent with the observation that the temperature variation of shallower turtle nests tends to be greater (Spotila et al. 1987) than in deeper nests. Periods of little or no rain were associated with warmer sand temperatures at all depths.

\section{Weather and sea turtle nest incubation season}

In south Florida the loggerhead sea turtle nesting season begins in late April and ends approximately in August, so nests incubate into October. The rainy season is defined as the months of the year when south Florida receives roughly $70 \%$ of its annual rain (NWS 2013); this usually spans May to October. Hurricane season is roughly June to November. These 3 ranges coincide, suggesting that the rainy season, including the hurricane season, has the potential to impact sea turtle sex ratios. Low rainfall amounts contributed to the lack of male hatchlings in our 2010, 2011, and the majority of 2012 and 2013 samples. However, early season nests in 2012 and 2013 had male-biased sex ratios; these nests experienced cooler temperatures from heavier precipitation in the early portion of the nesting season. Early season nests in all 4 years began incubation at cooler temperatures that rapidly increased, likely due to a decrease in rainfall as the season progressed.

Hot nesting seasons: 2010 and 2011

In 2010 and 2011, temperatures remained above the upper boundary of the TRT throughout the TSP, suggesting all-female samples should occur (Fig. 2). Eggs cease embryonic diapause once they are laid (Miller 1997, Miller et al. 2003, Rafferty \& Reina 2012). At our site, sand temperature is near or above the pivotal temperature at the time eggs are laid. Consequently, eggs resumed development and remained well above the pivotal temperature for most of incubation. We examined incubation temperatures during both estimates of the TSP by dividing incubation duration into 2 separate categories: the entire middle third of incubation, TSP (33-66\% of incubation) and the later portion of the middle third, $\mathrm{TSP}_{\mathrm{L}}(50-66 \%$ of incubation). A previous study of other turtle species suggested the end of the TSP range (Yntema stages 23-27 of 30) is particularly important in sex differentiation based upon an increase in gonadal aromatase activity (Desvages et al. 1993) in embryos incubated at 27 and $30.5^{\circ} \mathrm{C}$. Temperatures during the 2 TSP ranges varied very little. Despite slight differences between portions of the TSP, most of our nest temperatures during both TSP estimates remained above the pivotal temperature as well as the upper TRT boundary (except for very brief temperature drops due to rainfall). In 2010 and 2011, temperatures remained above the upper boundary of the TRT throughout the TSP, which is supported by all female samples in these years (Fig. 2). Nests in 2010 and 2011 experienced less rainfall and warmer ambient temperatures, causing nest temperatures to increase rapidly and constantly throughout all nest incubation periods. Thus, nest temperatures during the $\mathrm{TSP}_{\mathrm{L}}$ in these years tended to be warmer compared to the entire TSP. In all 2010 and 2011 nests, temperatures during $\mathrm{TSP}_{\mathrm{L}}$ were above the pivotal temperature and mostly above the upper boundary of the TRT, in spite of rainfall events (Table 1).

Laparoscopic identification of the turtles' sex corresponded with expectations based on sampled nest temperatures. All 2010 and 2011 samples were females, which is consistent with the particularly 
high nest temperatures and minimal effects of local rainfall events. Although it is tempting to suggest that even a brief reduction in temperature might impact the clutch sex ratio, evidence from this study suggests that short duration temperature declines are unlikely to impact the sex ratio, at least when overall temperatures are warm (e.g. nest CC10-121 from the 2010 nesting season). Temporal models of nonlinear thermal effects on sex ratio, such as Georges et al. (1994) and Telemeco et al. (2013a), suggest that the daily proportion of development at or above a given temperature likely directs sex determination rather than single brief periods of temperature change. The Georges et al. (1994) approach also considers that development is faster at warmer temperatures and slower at cooler temperatures. Consequently, isolated rainfall may have little effect on development in warm fast-developing nests. We conclude that it is only multiple and/or prolonged rainfall events that may impact the sex ratios.

Periods without rain and with very warm daily air temperatures coincided with rapid increases in nest temperature, particularly in 2010 and 2011. Our results are consistent with those of Segura \& Cajade (2010), who found that sand temperatures increased with decreasing rainfall. Several of our nests reached incubation temperatures that are above reported thermal maxima for sea turtle nests. Extreme temperatures, hot or cold, can disrupt embryonic development (Bustard \& Greenham 1968, McGehee 1979, Yntema \& Mrosovsky 1980, Telemeco et al. 2013b). Miller (1997) found that Australian Caretta caretta eggs incubated at temperatures $>33^{\circ} \mathrm{C}$ rarely hatch. The nests in the present study hatched when temperatures were higher, which suggests that Florida loggerheads may have a higher thermal threshold for successful incubation. However, hatch success generally was lower in the warmest nests. Hatchlings from nests that reached 36 to $37^{\circ} \mathrm{C}$ during the last half of development often died within a few hours of escaping the nest (J. Wyneken pers. observ.). Consequently, nests incubating during warm dry years tend to produce fewer hatchlings, and these are predominately females. Past studies of other taxa (Trivers \& Willard 1973, Kruuk et al. 1999) suggest that a greater proportion of females should be produced when conditions are unfavorable. Bull \& Charnov (1989) suggest that skewed primary sex allocation results from sex differences in fitness gains from the incubation environment. They also predict that the direction of a sex ratio bias is often toward the sex produced in the 'poorer' environment. The conclusions of these studies are consistent with our study's findings. Our results show a strong female bias across several extreme years, which were likely directed proximally by the strong temperature influence on sex determination, as well as ultimately by evolutionary implications of conditions unfavorable for successful development.

Rainfall and rainy season duration were less than average in the 2010 and 2011 nesting seasons. The 2010 rainy season had little cloud cover and widelyvarying rainfall, which likely contributed to high beach temperatures. For example, Palm Beach International Airport, located $40 \mathrm{~km}$ to the north of our site received only $63 \mathrm{~cm}$ (25 in) of rain, while Palm Beach Gardens ( $58 \mathrm{~km}$ to the northwest) received $113 \mathrm{~cm}$ (45 in). Local variation of rainfall amounts may result in differences in sex ratios among nesting beaches; however, we did not detect such. The short 2011 rainy season averaged $\sim 91 \mathrm{~cm}$ of rainfall over southeast Florida where our nests were located.

Wet nesting seasons: 2012 and 2013

Nests in 2012 and 2013 experienced conditions that differed from 2010 and 2011. Rainfall was greater than average in the 2012 and 2013 nesting seasons and the consequences were reflected in sampled hatchling sex ratios. The NWS characterized 2012 as cooler than 2010 and 2011, with temperatures near or below normal through November due to increased cloud cover and heavy rain (NWS 2012). The 2012 rainy season was extremely wet during the summer, particularly in southeast Florida, partially due to the effects of Tropical Storms Debby and Isaac and Hurricane Sandy. The 2013 rainy season was characterized by high summer rainfall amounts with each rainy season month experiencing above normal rainfall. Tropical Storm Andrea was the 2013 tropical system to impact south Florida's weather, which gave indirect effects in early June as its widespread rainfall and clouds likely contributed to male production in early season nests.

Early nest incubation temperatures in 2012 and 2013 remained within or close to the TRT but middle and late season nests experienced temperatures above the TRT. Early nests in 2012 and 2013 experienced frequent rainfall and cooler incubation temperatures, which likely contributed to the production of males in contrast to previous years. As with most biological systems, turtle development is slower at cooler temperatures (Yntema 1978, Georges et al. 1994). Thus, only multiple and/or prolonged rainfall events may impact the sex ratios. Slow early develop- 
ment may also have caused us to misidentify the TSP so that it occurred later than we expected (see Girondot et al. 2010), although that did not seem to be the case. The 2012 and 2013 early season nests experienced frequent periods of cooling throughout the estimated TSP and hatchling samples were strongly male biased (Table 1, Fig. 2).

In 2012, a large rainfall event of $11.5 \mathrm{~cm}$, followed by numerous smaller rainy periods, caused late season nest temperatures to decline and remain within the TRT and near the pivotal temperature. However, all resulting lower temperatures occurred after the estimated TSP and thus likely did not affect sex ratios. In 2013, mid-season nests experienced frequent rainfall before the TSP which lowered nest temperatures to $\sim 27^{\circ} \mathrm{C}$; however, for the remainder of incubation (including the TSP) little rain fell and clutch temperatures rapidly increased above $35^{\circ} \mathrm{C}$ (Fig. 2). Late season nests in 2013 also experienced high temperatures but a $\sim 8.7 \mathrm{~cm}$ rainfall event and subsequent smaller rainfall amounts led to fluctuating temperatures rather than the steady increase experienced by early and middle season nests. The last nest of the season (CC13-662) experienced lower temperatures than other late season nests. During its TSP, temperatures decreased to $\sim 28^{\circ} \mathrm{C}$ and remained within the TRT (Fig. 2). These lower temperatures likely explain its $90 \%$ female sex ratio compared to the $100 \%$ female sex ratios of the middle and other late season nests. However, by sampling $\sim 10 \%$ of the clutch on average $(13 \%$ or more of the emergent hatchling), we cannot rule out that some of our samples may be biased. In 2012, all sampled nests experienced temperatures below the pivotal temperature during $\mathrm{TSP}_{\mathrm{L}}$ except for nest CC12-775, the last sampled nest of the season, which was relocated after the TSP to a higher and drier location due to the threat of Tropical Storm Isaac. This nest experienced the warmest temperatures of the season, which likely prevented nest cooling during periods of rain. Similar to past years, all 2012 nests experienced temperatures above the TRT but heavy rainfall events kept high temperatures brief (Fig. 2). During TSP $_{\mathrm{L}}$ early 2013 nests experienced temperatures below the pivotal temperature and never exceeded the upper boundary of the TRT, while mid- and late season nests exceeded both the pivotal temperature and the TRT. The last sampled nest of the season experienced fluctuating temperatures that fell below the pivotal temperature but remained within the TRT during $\mathrm{TSP}_{\mathrm{L}}$.

Loggerhead nesting habits may also contribute to the high female sex bias of their nests. Loggerhead turtles tend to nest in the middle of the beach (sea- ward of the dune foot; Wood \& Bjorndal 2000), consequently their nests are seldom shaded, and their nests are relatively shallow. Loggerheads nesting in Greece tend to nest away from the water and close to, but not beyond, the vegetation line (Hays \& Speakman 1993). All sampled nests in the present study were seaward of the vegetation line but varied in proximity to the high tide line. A nest's distance from the water may also influence incubation conditions. Sands higher and further away from the water tend be warmer and have less moisture (Hays \& Speakman 1993, Wood \& Bjorndal 2000). Consequently, nests closer to the water may be moister, which can impact the way they respond to changing temperature. Our study highlights the effects that rainfall has on nest temperature because it is often cool and because once sand is moist it requires more heat energy to raise the temperature than drier sands due to higher specific heat capacity and thermal inertia from increased water content (Idso et al. 1975a, Reginato et al. 1976, Lakshmi et al. 2003).

Studies quantifying the effect of rainfall on nests have been inconsistent in their findings. Jourdan \& Fuentes (2013) suggest that manually wetting nests may not reduce sand temperatures in hot areas. They report that sprinkling nests with water during the day actually increased sand temperatures. However, Naro-Maciel et al. (1999) reported that $2 \mathrm{~h}$ of sprinkling decreased nest temperature by $\sim 1^{\circ} \mathrm{C}$. Consequently, the effects may vary with specific local conditions, including rainfall amount and duration.

While sex determination in sea turtles is primarily directed by temperature (Bull 1980, Mrosovsky \& Yntema 1980, Standora \& Spotila 1985, Wibbels 2003, reviewed in Valenzuela \& Lance 2004), the specific response mechanisms to temperature remain elusive. Here we focus on the relationships among nest temperature, factors that modify temperature effects, and hatchling sex ratios. An understanding of the impact of rainfall on the nest temperature and sex ratios is important because it identifies key responses by developing eggs that eventually impact sea turtle production. Increasing air temperatures increase evaporation, which leads to greater precipitation in some regions (IPCC 2007). The IPCC reports that average global temperatures have increased, and along with that, so has average global precipitation. However, there is large variation among regions. It is particularly important to understand what changes in temperature and precipitation imply for species that rely upon them. In addition, understanding the impacts of increased rain and temperature together are necessary to implement appropriate manage- 
ment strategies. Based upon the relationship we found between nest temperatures and heavy vs. sparse rainfall, future studies on hatchling sex ratios relative to environment should include effects of both moisture and temperature. Understanding the impact of rainfall as well as temperature may allow biologists not only to better predict hatchling sex ratio biases but also to anticipate the effects of changing temperature and precipitation on sex ratios.

Acknowledgements. We thank E. Frazier, R. Murphey, and J. Nambu, who guided A.L.'s participation in The National Science Foundation Undergraduate Research \& Mentoring Program (\#0829250). Grants to J.W. from the Disney Worldwide Conservation Fund, SaveOurSeas Foundation, Nelligan Sea Turtle Fund, and personal funds supported this project. This study would not have been possible without the generous help of Gumbo Limbo Nature Center's Sea Turtle Specialists, L. Bachler, M. Rogers, K. Rusenko, B. Tezak, and N. Warraich. S. Libreros, R. Garcia, S. Epperly, F. Janzen, M. J. Saunders, M. Salmon and an anonymous reviewer provided constructive criticism that improved this manuscript.

\section{LITERATURE CITED}

Blair K (2005) Determination of sex ratios and their relationship to the nest temperature of loggerhead sea turtle (Caretta caretta, L.) hatchlings produced along the southeastern Atlantic coast of the United States. MS thesis, Florida Atlantic University, Boca Raton, FL

Bull JJ (1980) Sex determination in reptiles. Q Rev Biol 55: $3-21$

Bull JJ (1985) Sex ratio and nest temperature in turtles: comparing field and laboratory data. Ecology 66:1115-1122

Bull JJ, Charnov EL (1989) Enigmatic reptilian sex ratios. Evolution 43:1561-1566

Bustard RH, Greenham P (1968) Physical and chemical factors affecting hatching in the green sea turtle, Chelonia mydas (L.). Ecology 49:269-276

Cagle KD, Packard GC, Miller K, Packard MJ (1993) Effects of the microclimate in natural nests on development of embryonic painted turtles, Chrysemys picta. Funct Ecol 7:653-660

Carthy RR, Foley AM, Matsuzawa Y (2003) Incubation environments of loggerhead turtle nests: effects on hatching success and hatchling characteristics. In: Bolten $A B$, Witherington BE (eds) Loggerhead sea turtles. Smithsonian Institution, Washington, DC, p 144-153

Desvages G, Girondot M, Pieau C (1993) Sensitive stages for the effects of temperature on gonadal aromatase activity in embryos of the marine turtle Dermochelys coriacea. Gen Comp Endocrinol 92:54-61

Finkler MS (2006) Does variation in soil water content induce variation in the size of hatchling snapping turtles (Chelydra serpentina)? Copeia 769-777

Georges A, Limpus C, Stoutjesdijk R (1994) Hatchling sex in the marine turtles Caretta caretta is determined by proportion of development at a temperature, not daily duration of exposure. J Exp Zool 270:432-444

Georges A, Doody S, Beggs K, Young J (2004) Thermal models of TSD under laboratory and field conditions. In: Valenzuela N, Lance V (eds) Temperature-dependent sex determination in vertebrates. Smithsonian Institution Scholarly Press, Washington, DC, p 79-89

Girondot M (1999) Statistical description of temperaturedependent sex determination using maximum likelihood. Evol Ecol Res 1:479-486

Girondot M, Ben Hassine S, Sellos C, Godfrey M, Guillon JM (2010) Modeling thermal influence on animal growth and sex determination in reptiles: being closer to the target gives new views. Sex Dev 4:29-38

Godfrey MH, Barreto R, Mrosovsky N (1996) Estimating past and present sex ratios of sea turtles in Suriname. Can J Zool 74:267-277

> Hays G, Speakman J (1993) Nest placement by loggerhead turtles, Caretta caretta. Anim Behav 45:47-53

Hays GC, Ashworth JS, Barnsley MJ, Broderick AC and others (2001) The importance of sand albedo for the thermal conditions on sea turtle nesting beaches. Oikos 93:87-94

> Houghton JDR, Myers AE, Lloyd C, King RS, Isaacs C, Hays GC (2007) Protracted rainfall decreases temperature within leatherback turtle (Dermochelys coriacea) clutches in Grenada, West Indies: ecological implications for a species displaying temperature dependent sex determination. J Exp Mar Biol Ecol 345:71-77

Idso S, Jackson R, Reginato R, Kimball B, Nakayama F (1975a) The dependence of bare soil albedo on soil water content. J Appl Meteorol 14:109-114

IPCC (2007) Contribution of Working Group I to the Fourth Assessment Report of the Intergovernmental Panel on Climate Change. Cambridge University Press, Cambridge

Jourdan J, Fuentes, MMPB (2013) Effectiveness of strategies at reducing sand temperature to mitigate potential impacts from changes in environmental temperature on sea turtle reproductive output. Mitig Adapt Strateg Glob Change 20:121-133

Kraemer JE, Bell R (1980) Rain-induced mortality of eggs and hatchlings of loggerhead sea turtles (Caretta caretta) on the Georgia coast. Herpetologica 36:72-77

Kruuk LE, Clutton-Brock TH, Albon SD, Pemberton JM, Guinness FE (1999) Population density affects sex ratio variation in red deer. Nature 399:459-461

Lakshmi V, Jackson TJ, Zehrfuhs D (2003) Soil moisturetemperature relationships: results from 2 field experiments. Hydrol Processes 17:3041-3057

LeBlanc AM, Wibbels T (2009) Effect of daily water treatment on hatchling sex ratios in a turtles with temperature-dependent sex determination. J Exp Biol 311A: 68-72

Matsuzawa Y, Sato K, Sakamoto W, Bjorndal K (2002) Seasonal fluctuations in sand temperature: effects on the incubation period and mortality of loggerhead sea turtle (Caretta caretta) pre-emergent hatchlings in Minabe, Japan. Mar Biol 140:639-646

McGehee MA (1979) Factors affecting the hatching success of loggerhead sea turtle eggs (Caretta caretta). MS thesis, University of Central Florida, Orlando, FL

McGehee MA (1990) Effects of moisture on eggs and hatchlings of loggerhead sea turtles (Caretta caretta). Herpetologica 46:251-258

Miller JD (1997) Reproduction in sea turtles. In: Lutz PL, Musick JA, Wyneken J (eds) The biology of sea turtles, Vol. II, CRC Press, Boca Raton, FL, p 51-81

Miller JD, Limpus CJ (1981) Incubation period and sexual differentiation in the green turtle Chelonia mydas L. In: Proceedings of the Melbourne Herpetological Symposium. Zoological Board of Victoria, Parkville, Victoria, p 66-73 
Miller JD, Limpus CJ, Godfrey MH (2003) Nest site selection, oviposition, eggs, development, hatching, and emergence of loggerhead turtles. In: Bolton $A B$, Witherington $\mathrm{BE}$ (eds) Loggerhead sea turtles. Johns Hopkins University Press, Baltimore, MD, p 125-143

Mrosovsky N (1988) Pivotal temperature for loggerhead turtles (Caretta caretta) from northern and southern nesting beaches. Can J Zool 66:661-669

Mrosovsky N (1994) Sex ratios of sea turtles. J Exp Zool 270: $16-27$

Mrosovsky N, Provancha J (1992) Sex ratio of hatchling loggerhead sea turtles: data and estimates from a 5-year study. Can J Zool 70:530-538

Mrosovsky N, Yntema CL (1980) Temperature dependence of sexual differentiation in sea turtles: implications for conservation practices. Biol Conserv 18:271-280

Naro-Maciel E, Mrosovsky N, Marcovaldi MA (1999) Thermal profiles of sea turtle hatcheries and nesting areas at Praia do Forte, Brazil. Chelonian Conserv Biol 3:407-413

NWS (National Weather Service) (2010) 2010 Rainy Season Underway. US Department of Commerce, National Oceanic and Atmospheric Administration, National Marine Fisheries Service. National Weather Service, Weather Forecast Office. Miami, FL. www.srh.noaa.gov/images/ mfl/news/RainySeason2010.pdf (accessed 13 Jul 2013)

NWS (National Weather Service) (2011) South Florida Dry Season Outlook 2011-2012. US Department of Commerce, National Oceanic and Atmospheric Administration, National Marine Fisheries Service. National Weather Service, Weather Forecast Office. Miami, FL. http:// www.srh.noaa.gov/images/mfl/news/2011RainySeasonSummary.pdf (accessed 21 Jul 2013)

NWS (National Weather Service) (2012) South Florida Dry Season Outlook 2012-2013. US Department of Commerce, National Oceanic and Atmospheric Administration, National Marine Fisheries Service. National Weather Service, Weather Forecast Office. Miami, FL. www. srh.noaa.gov/images/mfl/news/DrySeasonOutlook1213. pdf (accessed 21 Jul 2013)

NWS (National Weather Service) (2013) South Florida Dry Season Outlook 2013-2014. US Department of Commerce, National Oceanic and Atmospheric Administration, National Marine Fisheries Service. National Weather Service, Weather Forecast Office. Miami, FL. www. srh.noaa.gov/images/mfl/news/DrySeasonRelease2013. pdf (accessed 26 Mar 2014)

Packard GC, Packard MJ, Miller K, Boardman TJ (1987) Influence of moisture, temperature, and substrate on snapping turtle eggs and embryos. Ecology 68:983-993

Packard GC, Packard MJ, Birchard GF (1989) Sexual differentiation and hatching success by painted turtles incubating in different thermal and hydric environments. Herpetologica 45:385-392

Pieau C, Girondot M, Desvages G, Dorizzi M, RichardMercier N, Zaborski P (1995) Temperature variation and sex determination in reptilia. J Exp Med 13:516-523

Rafferty AR, Reina RD (2012) Arrested embryonic development: a review of strategies to delay hatching in egg-laying reptiles. Proc R Soc B Biol Sci 279:2299-2308

Ragotzkie R (1959) Mortality of loggerhead turtle eggs from excessive rainfall. Ecology 40:303-305

Raynaud A, Pieau C (1985) Embryonic development of the genital system. In: Gans C, Billett F (eds) Biology of the Reptilia. John Wiley \& Sons, New York, NY, p 149-300
Reginato RJ, Idso S, Vedder J, Jackson R, Blanchard M, Goettelman R (1976) Soil water content and evaporation determined by thermal parameters obtained from ground based and remote measurements. J Geophys Res 81:1617-1620

Rogers M (2013) Hatchling sex ratios and nest temperaturesex ratio response of 3 South Florida marine turtle species (Caretta caretta L., Chelona mydas L., and Dermochelys coriacea V.). MS thesis, Florida Atlantic University, Boca Raton, FL

Segura LN, Cajade R (2010) The effects of sand temperature on pre-emergent green sea turtle hatchlings. Herpetol Conserv Biol 5:196-206

SFWMD (South Florida Water Management District) (2013) DHYDRO. www.sfwmd.gov

Spotila JR, Standora EA, Morreale S, Ruiz GJ (1987) Temperature dependent sex determination in the Green turtle (Chelonia mydas): effects on the sex ratio on a natural nesting beach. Herpetologica 43:74-81

Standora EA, Spotila JR (1985) Temperature-dependent sex determination in sea turtles. Copeia 3:711-722

Telemeco RS, Abbott KC, Janzen FJ (2013a) Modeling the effects of climate change-induced shifts in reproductive phenology on temperature-dependent traits. Am Nat 181:637-648

Telemeco RS, Warner DA, Reida MK, Janzen FJ (2013b) Extreme developmental temperatures result in morphological abnormalities in painted turtles (Chrysemys picta): a climate change perspective. Integr Zool 8: 197-208

TEWG (Turtle Expert Working Group) (2009) An assessment of the loggerhead turtle population in the western North Atlantic. NOAA Tech Memo NMFS-SEFSC575

Trivers RL, Willard DE (1973) Natural selection of parental ability to vary the sex ratio of offspring. Science 179: 90-92

Valenzuela N, Lance V (eds) (2004) Temperature-dependent sex determination in vertebrates. Smithsonian Institution, Washington, DC

Wibbels T (2003) Critical approaches to sex determination in sea turtles. In: Lutz PL, Musick JA, Wyneken J (eds) The biology of sea turtles, Vol II. CRC Press, Boca Raton, FL, p 103-134

> Wood DW, Bjorndal KA (2000) Relation of temperature, moisture, salinity, and slope to nest site selection in loggerhead sea turtles. Copeia 119-128

Wyneken J, Lolavar A (2015) Loggerhead sea turtle environmental sex determination: implications of moisture and temperature for climate change based predictions for species survival. J Exp Zool (Mol Dev Evol) 323B: 295-314

Wyneken J, Epperly SP, Crowder LB, Vaughan J, Esper KB (2007) Determining sex in post hatchling loggerhead sea turtles using multiple gonadal and accessory duct characteristics. Herpetologica 63:19-30

Yntema CL (1978) Incubation times for eggs of the turtle Chelydra serpentina (Testudines: Chelydridae) at various temperatures. Herpetologica 34:274-277

Yntema CL, Mrosovsky N (1980) Sexual differentiation in hatchling loggerheads incubated at different controlled temperatures. Herpetologica 36:33-36

Zar JH (1999) Biostatistical analysis, 4th edn. Prentice Hall, Upper Saddle River, NJ

Submitted: December 22, 2014; Accepted: June 15, 2016

Proofs received from author(s): September 10, 2015 